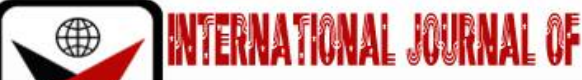

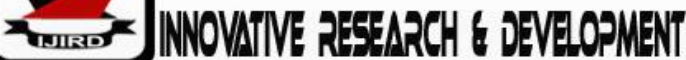

ISSN 2278-0211 (Online)

\section{Prioritizing Barriers to Circular Business Model Innovation in Iran Renewable Energy Sector: A Multiple Case Study}

\author{
Saeedeh Ghoochkanloo
}

Economic Researcher, Department of Research, Kotra, Tehran, Iran

\begin{abstract}
:
Sustainable development holds the key to assembling stable and secure societies and is crucial because it may be a thanks to conserve natural resources. Resource efficiency is becoming an increasingly critical factor for long-term success of all sectors including renewable energy. Circular economy is main pillar of sustainable development and may lead to resource efficiency, real environmental benefits and economic feasibility. The adoption of circular business models and devise new configurations and innovation at company level, may be a key element within the transition to a circular economy and creating values. In this paper, we prioritized the barriers already defined for circular business model innovation in renewable energy sector in Iran by investigating ten companies active during this field. The results indicate that almost all companies believed organizational level barriers should be considered mostly and therefore the key barriers are special product design requirements, hesitant approach to promoting the circular economy agenda and regulatory barriers, respectively. The final result of the research should aid managers in renewable energy industry to develop effective action towards more successful implementation of circular business model innovation.
\end{abstract}

Keywords: Sustainable development, renewable energy, circular economy, circular business model, circular business model innovation

\section{Introduction}

\subsection{Importance of Circular Business Model Innovation in Renewable Energy}

The ultimate aim of sustainable development is to realize a balance among environmental, economic and social sustainability, thus, making these the pillars on which sustainable development rests (Mensah \& Ricart Casadevall, 2019). The circular economy concept and promoting circularity aims to outwork sustainable development. it's links to several of the 17 Sustainable Development Goals (SDGs) approved by the world organization in 2015. The goal of a circular economy is to keep up the worth of products, materials and resources within the economy for as long as possible and minimize the generation of waste.

A circular economy should cause lower energy consumption and carbonic acid gas emissions, modernize and transform the economy and support job creation (Zamparutti, et. Al. 2017). Circular economy and renewable energy have to come together, to cover a really sustainable transition towards a low-carbon future (Circusol Program, 2019).

The rapid deployment of renewable energy has been driven mainly by a large range of objectives described because the pursuit of sustainable development (Sawin et al., 2016). Altogether, these objectives can be described because the pursuit of sustainable development, where economic prosperity is advanced round the world while negative impacts are Manuscript minimized. round the world, communities, islands, and cities have found that creating the transition to $100 \%$ renewable energy is basically a matter of political will which the specified technologies already are at hand. Achieving energy efficiencies of processes, not only utilizing sustainable energy resources, but also implementation of circular business model plays a vital role.

So as to boost the transformation of companies, industries, and whole economies to adapt and reach application of a circular economy, a system-wide innovation changing the entire processes useful creation is commonly needed (Antikainen \& Valkokari, 2016). Rethinking the business model to incorporate circular business model components (i.e. value recreation and redelivery, value recapture and an extended value proposition) enables an organization to align the worth creation logic with circular principles, and although an organization can work with the mixing of a subset of the circular business model components within the existing business model, the simplest results are attained from a concerted effort that takes all of those elements into consideration (Geissdoerfer et al., 2018).

For affordable, sustainable energy for all and temperature change mitigation, when the entire business ecosystem and its dynamics are changing, it's important to understand the way to innovate new disruptive business models during this environment. In this regard, this paper attempts to review barriers to circular business model innovation and prioritizing these barriers for renewable energy sector in Iran. 


\subsection{Relevant Related Literature}

According to the aim of this paper, the literature of the research is divided in two parts of relation between sustainable development and renewable energy and concept of circular economy and business model innovation.

\subsubsection{Sustainable}

Development and Renewable Energy The concept of conserving resources for future generations that proposed for sustainable development by the Brundtland Commission, is one in every of the key features that discern sustainable development policy from traditional environmental policy. The general goal of sustainable development is the long-term consistency of the economy and environment; this can be only achievable by ratification of economic, environmental, and social concerns throughout the decision-making process (Dernbach J. C., 2003; Cerin, 2006; Stoddart, 2011).

Energy is that the lifeblood of recent economies and societies. As such, the management and development of energy resources form an utter priority from a sustainable development outlook. Because the conventional sources for power generation reach their peaks, renewable energy technologies are the hope for the globe (Gyamfi, 2018). Sustainable development is often defined as preserving the number of the sources utilized by society for today's needs at point which will not deprive future generations of their needs (Güney, 2019).

The literature on the effect of renewable energy on sustainable development is sort of insufficient because they mostly use the expansion rate and similar variables as the sustainable development variables within the studies that investigate the link between renewable energy and sustainable development.

\subsubsection{Circular Economy and Business Model Innovation}

Still, circular economy is an emerging implication (Velenturf et al., 2019) and has become considered a key research topic in a manifold of disciplines, such as sustainability management, innovation, and new product development (Linder \& Williander, 2017). The concept of circular economy has been suggested as a thinkable route to sustainable development and the adoption of circular business models at a company level is a key element in the mutation to a circular economy (Kirchherr et al., 2017). The circular economy has been attaining tension as a way to deal with acceding local, national, and global sustainability (Schroeder et al., 2019).

Circular business model includes application of circular economy practices such as maximization of material and energy efficiency, creating value from waste, etc. A business model is typically depicted by a value proposition, value creation and delivery and value capture mechanisms (Magaretta, 2002). Business models are understood as a management tool to study the organizational structure and value creation processes of businesses, defining the core logic of how a company creates, delivers, and captures value (Osterwalder \& Pigneur, 2010, Geissdoerfer et al., 2018).

\begin{tabular}{|c|c|c|}
\hline Value Dimension & Corresponding Question & Business Model Elements \\
\hline Value proposition & $\begin{array}{c}\text { What value is provided and to } \\
\text { whom? }\end{array}$ & $\begin{array}{c}\text { Product/service offer and value } \\
\text { proposition Customer segment }\end{array}$ \\
\hline $\begin{array}{c}\text { Value creation and } \\
\text { delivery Resources and } \\
\text { capabilities }\end{array}$ & How is value provided? & Partner network Value chain activities \\
\hline Value capture & $\begin{array}{c}\text { How does the company make } \\
\text { profit and capture other forms of } \\
\text { value? }\end{array}$ & $\begin{array}{c}\text { Financial structure (costs and revenue } \\
\text { flows) }\end{array}$ \\
\hline
\end{tabular}

Table 1: Core Activities in a Business Model (Osterwalder and Pigneur, 2010)

A circular business model can define as kind of sustainable business model (Adams et al., 2016;) that matures environmental and economic value creation by changing the business logic from generating profits from one-time sales of goods, to bringing forth profits from a continual flow of reused materials and products over time (Bakker et al., 2014) by capitalizing on the value embedded in used products (Bocken et al., 2016; Linder and Williander, 2017).

Innovating the business model can take two broad forms, i.e., the design of an entirely new business model, or the reconfiguration of the elements of an existing business model (Zot 2011). Circular business model innovation the process of reconfiguring an existing linear business model to include circular business model components, or the process of reconfiguring an existing circular business model to include better versions of these circular business model components. In start-ups, circular business model innovation defines as the process of crafting a circular business model based on those circular business model components from the ground up (Guldmann and Huulgaard, 2020).

\section{Methodology}

This study was an analytical field research. Factor analysis is used when cases have been measured on several persistent variables and it is wished to see whether these variables can be diminished to a smaller set of variables (Chris 2004). The case companies for the multiple-case study were selected among a group of 14 companies active in Iran smart and solar energy field. In case study research, it is typical to select cases by applying specific criteria, instead of selecting a random or stratified sample (Eisenhardt, 1989). The instrument used in this research is researcher made questionnaire based on Likert (Five-point) designed by using the information of barriers found by Guldmann and Huulgaard (2020). In this study, validity of questionnaire has been established using a panel of experts and reliability was confirmed by the Cronbach's alpha coefficient $(\alpha>0.7)$. Statistical analysis has been performed by the SPSS Version 26. 


\section{Results}

Considering Table 2, the Cronbach's alpha acknowledged the validity of model. As well as, the KMO test which has done to avouch sufficiency of sampling which is considered 0.5. Since all are higher than required, the reliability of the research and competence of sampling has been confirmed. As evident in the Table 2, we defined which of the indicators in each dimension is of the most extensive importance and have been complied (factor loadings above 0.4 were desirable and all factors loaded above that). Those with the highest factor loading are of greater validity.

\begin{tabular}{|c|c|c|c|c|c|c|}
\hline Barriers & Indicators & $\begin{array}{c}\text { Rotated } \\
\text { Component }\end{array}$ & T-Values & Mean & $\begin{array}{c}\text { Cronbach's } \\
\text { alpha }\end{array}$ & KMO \\
\hline \multirow{5}{*}{$\begin{array}{l}\text { Market and } \\
\text { institutional } \\
\text { level }\end{array}$} & Regulatory barriers & 0.896 & 18.923 & 3.50 & \multirow[t]{5}{*}{0.799} & \multirow[t]{5}{*}{0.726} \\
\hline & $\begin{array}{c}\text { Low price of virgin raw } \\
\text { materials compared to recycled } \\
\text { materials }\end{array}$ & 0.695 & 20.840 & 4.00 & & \\
\hline & $\begin{array}{l}\text { Difficulty securing funding for } \\
\text { circular business models }\end{array}$ & 0.824 & 26.250 & 3.55 & & \\
\hline & Unclear Market demand & 0.654 & 19.230 & 3.55 & & \\
\hline & $\begin{array}{l}\text { Public procurement policies not } \\
\text { sustainability oriented }\end{array}$ & 0.799 & 16.088 & 3.80 & & \\
\hline \multirow[t]{7}{*}{$\begin{array}{l}\text { Value chain } \\
\text { level }\end{array}$} & $\begin{array}{l}\text { Investments in existing } \\
\text { manufacturing facilities and } \\
\text { value chain }\end{array}$ & 0.696 & 30.485 & 3.75 & \multirow[t]{7}{*}{0.860} & \multirow[t]{7}{*}{0.771} \\
\hline & $\begin{array}{l}\text { Concerns about quality control } \\
\text { of returned goods }\end{array}$ & 0.618 & 20.913 & 3.55 & & \\
\hline & $\begin{array}{l}\text { Concerns about consistency of } \\
\text { flow of returned goods }\end{array}$ & 0.878 & 23.106 & 3.85 & & \\
\hline & Dispersed, complex value chains & 0.677 & 18.653 & 3.65 & & \\
\hline & $\begin{array}{c}\text { Reluctance to involve external } \\
\text { stakeholders in circular } \\
\text { business model innovation } \\
\text { activities }\end{array}$ & 0.798 & 19.230 & 3.55 & & \\
\hline & $\begin{array}{l}\text { Takes time to build new } \\
\text { partnerships and mutual trust }\end{array}$ & 0.543 & 17.490 & 3.65 & & \\
\hline & $\begin{array}{c}\text { Lack of knowledge or } \\
\text { competencies in value chain }\end{array}$ & 0.519 & 19.714 & 3.75 & & \\
\hline \multirow[t]{9}{*}{$\begin{array}{l}\text { Organization } \\
\text { al level }\end{array}$} & $\begin{array}{l}\text { Narrow focus of existing } \\
\text { sustainability strategies }\end{array}$ & 0.830 & 21.354 & 3.60 & \multirow[t]{9}{*}{0.856} & \multirow[t]{9}{*}{0.749} \\
\hline & $\begin{array}{l}\text { Difficulty attaining management } \\
\text { buy-in }\end{array}$ & 0.734 & 22.132 & 3.90 & & \\
\hline & $\begin{array}{l}\text { ROI and similar requirements } \\
\text { for new business ventures }\end{array}$ & 0.802 & 23.657 & 3.60 & & \\
\hline & Cannibalization concerns & 0.578 & 18.448 & 3.85 & & \\
\hline & $\begin{array}{l}\text { Little evidence of financial } \\
\text { and/or environmental benefits }\end{array}$ & 0.529 & 20.650 & 3.70 & & \\
\hline & $\begin{array}{c}\text { Lack of resources, knowledge or } \\
\text { competencies in-house }\end{array}$ & 0.641 & 20.571 & 3.50 & & \\
\hline & $\begin{array}{c}\text { Uncertainty about legislation in } \\
\text { this field }\end{array}$ & 0.857 & 22.584 & 3.70 & & \\
\hline & $\begin{array}{l}\text { Difficulty establishing cross- } \\
\text { organizational collaboration }\end{array}$ & 0.559 & 19.140 & 3.70 & & \\
\hline & $\begin{array}{c}\text { Special product design } \\
\text { requirements }\end{array}$ & 0.905 & 33.356 & 3.65 & & \\
\hline \multirow[t]{4}{*}{$\begin{array}{l}\text { Employee } \\
\text { level }\end{array}$} & $\begin{array}{l}\text { Lack of knowledge about } \\
\text { circular economy and circular } \\
\text { business models }\end{array}$ & 0.511 & 22.480 & 3.45 & \multirow[t]{4}{*}{0.764} & \multirow[t]{4}{*}{0.716} \\
\hline & $\begin{array}{l}\text { Hesitant approach to promoting } \\
\text { the circular economy agenda }\end{array}$ & 0.904 & 20.290 & 3.25 & & \\
\hline & $\begin{array}{c}\text { Prevailing linear business model } \\
\text { structures and thinking }\end{array}$ & 0.791 & 21.906 & 3.65 & & \\
\hline & $\begin{array}{l}\text { Incentive structure supporting } \\
\text { linear business models }\end{array}$ & 0.606 & 20.168 & 3.40 & & \\
\hline
\end{tabular}

Table 2: Analysis of the Structure of Analytical Research 
Also, regarding the Table 2, the amount of t-values is acceptable. Table 3 , indicates the factor loading of components which calculates as:

$W f_{i} \frac{\lambda_{i}}{\sum_{j-1}^{k} \lambda_{j}} \times 100$

\begin{tabular}{|c|c|c|c|c|}
\hline Barriers & $\begin{array}{c}\text { Market and institutional } \\
\text { level }\end{array}$ & $\begin{array}{c}\text { Value chain } \\
\text { level }\end{array}$ & $\begin{array}{c}\text { Organizational } \\
\text { level }\end{array}$ & $\begin{array}{c}\text { Employee } \\
\text { level }\end{array}$ \\
\hline Factor Loading & 0.217 & 0.265 & 0.361 & 0.158 \\
\hline
\end{tabular}

Table 3: Factor Loading of Barriers in Sub Level

\section{Discussion}

The circular economy has been blazoned as a potential driver for sustainable development by business, academics, and policymakers. The adoption of circular business models at a company level, which is a key element in the transition to a circular economy, has nevertheless been slow and importance as well as necessity of innovation in business models is more obvious. This paper has contributed to prioritize the barriers already defined for circular business model innovation in renewable energy sector in Iran by investigating ten companies active in this field. Using literature, barriers to circular business model innovation was classified into four levels of market and institutional, value chain, organizational and employee. The results indicate that most companies believed organizational level barriers should be considered. As showed in factor analysis, the most important barrier in circular business model innovation are special product design requirements, hesitant approach to promoting the circular economy agenda and regulatory barriers, respectively. The Lack of knowledge about circular economy and circular business models indicator also has the least importance. So, the managers should put the most of their attention on how to deal with product designs and maybe acceptance of buyers to use rebuilt products. The research provides managers and other practitioners with a more complete outline of barriers that are existing in path to circular business model innovations.

\section{References}

i. Adams, R., Jeanrenaud, S., Bessant, J., Denyer, D., Overy, P., (2016). Sustainability-oriented innovation: a systematic review. Int. J. Manag. Rev. 18, 180e205.

ii. Antikainen, M., \& Valkokari, K. (2016). A Framework for Sustainable Circular Business Model Innovation. Technology Innovation Management Review, 6(7): 5-12.

iii. Bakker, C., den Hollander, M., van Hinte, E., Zijlstra, Y., (2014). Products that Last -Product Design for Circular Business Models, First ed. TU Delft, Delft, Netherlands.

iv. Bocken, N.M.P., Bakker, C., de Pauw, I., van der Grinten, B., (2016). Product design and business model strategies for a circular economy. J. Ind. Prod. Eng. 33, 308-320.

v. Cerin, P. (2006). Bringing economic opportunity into line with environmental influence: A Discussion on the Coase theorem and the Porter and van der Linde hypothesis. Ecological Economics, 209-225.

vi. Chris, D., (2004). Statistical Methods for Organizational Research: Theory and Practice.

vii. Dernbach, J. C. (2003). Achieving sustainable development: The Centrality and multiple facets of integrated decision making. Indiana Journal of Global Legal Studies, 247-285.

viii. Eisenhardt, K.M., (1989). Building theories from case study research. Acad.Manag.Rev. 14, 532 e550.

ix. Geissdoerfer, M., Vladimirova, D. \& Evans, E. (2018). Sustainable business model innovation: a review. J. Clean. Prod., 198, pp. 401-416.

x. Geissdoerfer, M., Morioka, S.N., de Carvalho, M.M., Evans, S., (2018). Business models and supply chains for the circular economy. J. Clean. Prod. 190, 712-721.

xi. Guldmann, E., \& Huulgaard, R. D. (2020). Barriers to circular business model innovation: A multiple-case study. Journal of Cleaner Production, 243, 118-160.

xii. Güney, T. (2019). Renewable energy, non-renewable energy and sustainable development. International Journal of Sustainable Development \& World Ecology, 26(5), 389-397.

xiii. Gyamfi, S., Derkyi, N. S.A., Asuamah., E. Y., Aduako, I. J.A. (2018). Chapter 6-Renewable Energy and Sustainable Development, Sustainable Hydropower in West Africa, Pages 75-94.

xiv. Kirchherr, J., Reike, D., \& Hekkert, M., (2017). Conceptualizing the circular economy: An analysis of 114 definitions. Resources, Conservation and Recycling, Volume 127, Pages 221-232.

xv. Linder, M., \& Williander, M. (2017). Circular business model innovation: inherent uncertainties. Business strategy and the environment, 26(2), 182-196.

xvi. Magretta, J. (2002). Why business models matter. Harv. Bus. Rev., 80, 86-92.

xvii. Mensah, J., \& Ricart Casadevall, S. (2019). Sustainable development: Meaning, history, principles, pillars, and implications for human action: Literature review. Cogent Social Sciences, 5(1), 1653531.

xviii. Osterwalder, A., \& Pigneur, Y. (2010). Business Model Generation: A Handbook for Visionaries, Game Changers, and Challengers. Hoboken, NJ: Wiley.

xix. Sawin, J.L., Sverrisson, F., \& Leidreiter. A., (2016). Renewable Energy and Sustainable Development, Accounting for Impacts on the Path to $100 \%$ Re. World Future Council

xx. Schaltegger, S., Hansen, E.G., Lüdeke-Freund, F., (2016). Business models for sustainability: origins, present research, and future avenues (editorial article). Organ. Environ. 29, 3-10. 
xxi. Schroeder, P., Anggraeni, K. and Weber, U. (2019), The Relevance of Circular Economy Practices to the Sustainable Development Goals. Journal of Industrial Ecology, 23: 77-95.

xxii. Stoddart, H. (2011). A Pocket guide to sustainable development governance. Stakeholder Forum.

xxiii. Velenturf, A.P., Archer, S.A., Gomes, H.I., Christgen, B., Lag-Brotons, A.J. \& Purnell. P., (2019). Circular economy and the matter of integrated resources. Sci. Total Environ. 689, pp. 963-969.

xxiv. Wang, K. (2019). Service-based Business Models for Circular Economy in the Solar Power Sector. https://www.circusol.eu/files/brand\%20resources/Circusol-Brochure-21x21cm.pdf

xxv. Zamparutti, T., Piirsalu, E., Joe, M., Moora, H. \& McNeill, A., (2017). Circular Economy with Focus on Waste, Renewable energy and Sustainable Bioenergy in Estonia. Policy Department A: Economy and Scientific Policy and Quality of Life Policies. European Parliament doi:.2861/52360

xxvi. Zott, C.; Amit, R.; Massa, L. (2011). The business model: Recent developments and future research. J. Manag. 37, 1019-1042. 